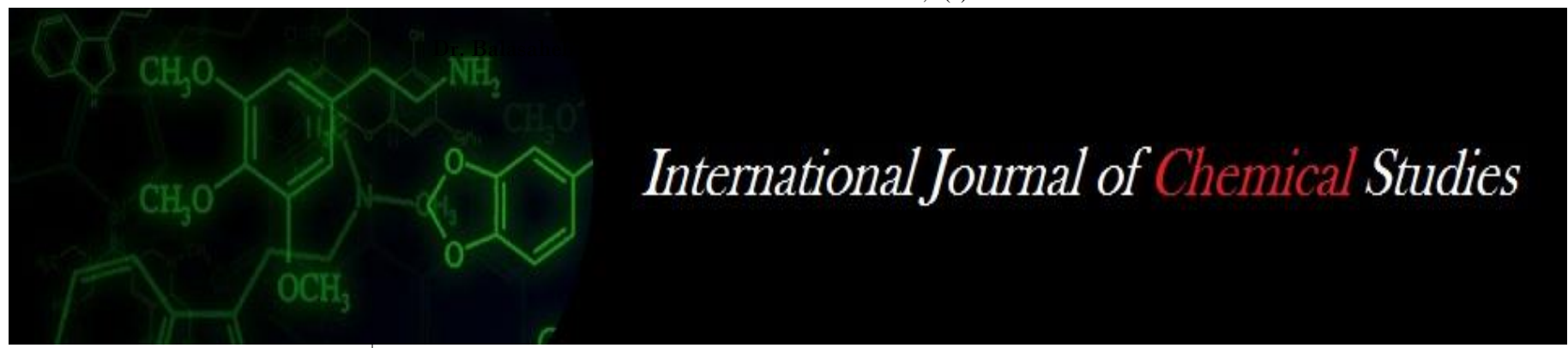

P-ISSN: 2349-8528

E-ISSN: 2321-4902

www.chemijournal.com

IJCS 2020; 8(2): 810-814

(C) 2020 IJCS

Received: 22-01-2020

Accepted: 26-02-2020

Tapas Kumar Halder

Assistant, Agricultur, Chemist,

Govt. of West Bengal, India

Ajit Kumar Dolui

Ex-Professor, Department of

Agricultural Chemistry \& Soil

Science, Institute of Agricultural

Science, University of Calcutta,

Kolkata, West Bengal, India

Dipankar Saha

Ex-Professor, Bidhan Chandra

Krishi Viswavidyalaya,

Mohanpur, Nadia, West Bengal, India
Corresponding Author:

Tapas Kumar Halder

Assistant, Agricultur, Chemist,

Govt. of West Bengal, India

\section{Influence of combined application of organic and inorganic amendments on nutrient status in a typic Haplaquept soil of West Bengal}

\author{
Tapas Kumar Halder, Ajit Kumar Dolui and Dipankar Saha
}

DOI: https://doi.org/10.22271/chemi.2020.v8.i21.8866

\begin{abstract}
Balanced nutrition based on soil test value is the key to sustain and improve soil productivity. Integrated management of organic, secondary and micronutrient inputs along with inorganic fertilizers in soils is required to prevent decline in soil fertility, crop productivity and sustainability. In present investigation is conducted to study the influence of farmyard manure (FYM), sulphur and zinc along with inorganic NPK fertilizers either alone or in combination on the nutrient availability in soil. Results revealed that use of FYM increased the organic carbon content and availability of nutrients over soil alone and soil treated with only inorganic fertilizers. Results further revealed that the beneficial effects of FYM got enhanced when it is applied along with S and Zn.
\end{abstract}

Keywords: Organic, secondary, micronutrient, farmyard manure

\section{Introduction}

Use of inorganic fertilizers has increased considerably to meet the higher nutrient requirements of the present day which creates imbalance in nutrient supply in soil. A suitable combination of secondary and micronutrients is an important factor that affects the productivity of the crops. Organic resources play a dominant role in soil properties through their short-term effects on nutrient supply and longer-term contribution to soil organic matter (SOM) formation (Palm et al., 2001) ${ }^{[1]}$. In order to supply all the nutrients to soil in adequate amount and to maintain its good health, it is necessary to use organic sources like FYM in combination with fertilizers. They not only supply macro-nutrients but also meet the demand of micro nutrients, besides improving soil health (Arbad and Ismail, 2011) ${ }^{[2]}$. Many studies have shown the possibility to increase the content of N, P, K by using sulphur fertilizers (Klikocka et al., 2017) ${ }^{[3]}$. $\mathrm{Zn}$ is a micro nutrient which is deficient in most of the soils of West Bengal (AICRPMSPE, 2015) ${ }^{[4]}$, plays a vital role in protein and starch synthesis, (Marschner, 1995) ${ }^{[5]}$, protect cell membrane against oxidative damage from superoxide radicals (Cakmak, 2000) ${ }^{[6]}$. Zinc deficiency has been recognized as an important and widespread nutritional disorder of rice (Niraj et al., 2014) ${ }^{[7]}$. The present investigation was, therefore conducted to monitor the changes in nutrient status of an alluvial soil amended with organic and inorganic fertilizers including $\mathrm{S}$ and $\mathrm{Zn}$.

\section{Materials and Methods}

Collection of soil sample

Composite soil sample was collected from a farmer's field situated at Gotra mouza in Chakdah block in the district of Nadia West Bengal. The soil has been classified as Typic Haplaquept by National Bureau of Soil Science (NBSS \& LUP). The field was generally cultivated for rice-mustard cropping sequence. The soils were collected prior to rice cultivation. The collected soil sample was air-dried, ground in wooden pestle and mortar and passed through 80 mesh seive. The soil sample was analyzed for different physical, chemical and microbiological parameters following standard analytical procedures and the data are presented in Table 1. Farm yard manure (FYM) used in the present experiment as treatment material was analyzed and the data are presented in Table 2. 
Table 1: Physical and chemical properties of the soil used for the incubation study

\begin{tabular}{|c|c|c|c|}
\hline Sl. No & Parameters & Result & Reference Method \\
\hline 1. & $\mathrm{pH}$ & 7.56 & Jackson, $1973^{[8]}$ \\
\hline 2. & Electrical Conductivity $\left(\mathrm{dsm}^{-1}\right)$ & 0.190 & Jackson, $1973^{[8]}$ \\
\hline 3. & Mechanical Separates & & Piper, $1966^{[9]}$ \\
\hline i) & Sand $\%$ & 16.8 & \\
\hline ii) & Silt $\%$ & 18.0 & \\
\hline iii) & Clay $\%$ & 65.2 & \\
\hline & Textural class & Clay loam & USDA, $1975^{[10]}$ \\
\hline 4. & Cation exchange capacity $\mathrm{C} \mathrm{mol}\left(\mathrm{p}+\mathrm{kg}^{-1}\right.$ & 24.6 & Schollen Berger and Simon, (1945) ${ }^{[11]}$ \\
\hline 5. & Organic carbon $(\%)$ & 0.52 & Walkley and Black, $1934^{[12]}$ \\
\hline 6. & Water holding capacity (\%) & 47.90 & Baruah and Barthakur,1997 [13] \\
\hline 7. & Total Nitrogen $(\%)$ & 0.088 & Stevenson, $1996^{[14]}$ \\
\hline 8. & Available $\left(\mathrm{NH}_{4}^{+}\right)$ & 123.47 & \multirow{2}{*}{ Bremner and Keeney, $1966^{[15]}$} \\
\hline 9 & Available $\left(\mathrm{NO}_{3}^{-}\right)$ & 24.16 & \\
\hline 10 & Available phosphorus $\left(\mathrm{kgha}^{-1}\right)$ & 36.34 & Olsen et al.,1954 [16] \\
\hline 11 & Available potassium $\left(\mathrm{kgha}^{-1}\right)$ & 150.74 & Jackson, $1973^{[8]}$ \\
\hline 12 & Available sulphur $\left(\mathrm{mg} \mathrm{kg}^{-1}\right)$ & 6.38 & Chesnin and Yien,1951 [17] \\
\hline 13. & Available $\mathrm{Zn}\left(\mathrm{mg} \mathrm{kg}^{-1}\right)$ & 0.56 & Lindsay \& Norvell, $1978^{[18]}$ \\
\hline 14 & Microbial biomass carbon (microg ramkg-1) & 95.36 & Joergenson, $1995^{[19]}$ \\
\hline 15 & USDA Nomenclature & Typic Haplaquept & USDA, $1975^{[10]}$ \\
\hline
\end{tabular}

Table 2: Characterization of FYM used in the incubation study

\begin{tabular}{|c|c|c|c|c|c|c|}
\hline Oxidizable Organic Carbon (\%) & $\mathbf{N}(\%)$ & $\mathbf{P}_{\mathbf{2}} \mathbf{O}_{\mathbf{5}}(\boldsymbol{\%})$ & $\mathbf{K}_{\mathbf{2}} \mathbf{O}(\boldsymbol{\%})$ & $\mathbf{S}(\boldsymbol{\%})$ & $\mathbf{Z n}(\boldsymbol{\%})$ & $\mathbf{C} / \mathbf{N}$ ratio \\
\hline 1.8 & 0.58 & 0.22 & 0.5 & 0.02 & 0.0027 & 18 \\
\hline
\end{tabular}

\section{Experimental setup and Methodology}

The laboratory experiment was conducted during SeptemberNovember 2014-2015 under controlled laboratory conditions in Department of Agricultural Chemistry and Soil Science, instate of Agricultural Science, University of Calcutta. Each pot containing three $\mathrm{kg}$ soils were incubated for a period of ninety days. Arable moisture level $(60 \%$ of water holding capacity of the soil) was maintained throughout the incubation study. Loss of moisture due to evaporation was replenished every alternate day by difference in weight. In order to ascertain the effect of added secondary and micronutrients along with NPK fertilizers and FYM, the following six treatment combinations in completely randomized design were adopted. All the treatments are replicated thrice.

\author{
$\mathrm{T}_{1} \quad$ Soil \\ $\mathrm{T}_{2} \quad$ Soil $+\mathrm{NPK}\left(\mathrm{N}-\mathrm{P}_{2} \mathrm{O}_{5}-\mathrm{K}_{2} \mathrm{O}\right.$ at $\left.60-30-30 \mathrm{Kg} \mathrm{ha}^{-1}\right)$ \\ $\mathrm{T}_{3} \quad$ Soil $+\mathrm{NPK}+\mathrm{FYM}(\mathrm{FYM}$ at $1 \%$ dry wt. of soil) \\ $\mathrm{T}_{4} \quad$ Soil $+\mathrm{NPK}+\mathrm{FYM}+\mathrm{S}\left(\mathrm{S}\right.$ at $\left.20 \mathrm{mgkg}^{-1}\right)$ \\ T5 $\quad$ Soil $+\mathrm{NPK}+\mathrm{FYM}+\mathrm{Zn}\left(\mathrm{Zn}\right.$ at $\left.10 \mathrm{mg} \mathrm{kg}^{-1}\right)$ \\ T6 Soil $+\mathrm{NPK}+\mathrm{FYM}+\mathrm{S}\left(\mathrm{S}\right.$ at $\left.20 \mathrm{mgkg}^{-1}\right)+\mathrm{Zn}\left(\mathrm{Zn}\right.$ at $\left.10 \mathrm{mg} \mathrm{kg}^{-1}\right)$
}

Treatment wise soils were applied with $\mathrm{N}, \mathrm{P}$ and $\mathrm{K}$ at 60, 30 and $30 \mathrm{Kg} \mathrm{ha}^{-1}$ as $\mathrm{N}, \mathrm{P}_{2} \mathrm{O}_{5}$ and $\mathrm{K}_{2} \mathrm{O}$ through Urea, Single super phosphate and Muriate of potash respectively. Well decomposed FYM was added as treatment material at $1 \%$ dry weight basis. Sulphur was applied through elemental sulphur (95\% purity) at $20 \mathrm{mgkg}_{-}{ }^{1}$ and $\mathrm{Zn}$ was applied through $\mathrm{Zn}$ EDTA $(12 \% \mathrm{Zn})$ at $10 \mathrm{mgkg}^{1}{ }^{1}$. All treatment materials were added to soil as basal soil on the $1^{\text {st }}$ day of experiment. Samples from each pot were analyzed on the $15^{\text {th }}, 30^{\text {th }}, 60^{\text {th }}$ and $90^{\text {th }}$ day of incubation study. Soils are analysed periodically for oxidisable organic carbon, available nitrogen, available phosphorus, available potassium, available sulphur, DTPA extractable $\mathrm{Zn}$ and Microbial Biomass carbon. Different soil parameters were analyzed statistically following the methods of Walter T. Federar (1927) ${ }^{[20]}$ to study the significance of means among treatments at different sampling stages of incubation study.

\section{Result and Discussion Organic Carbon}

Changes in the amount of oxidizable organic carbon in soil treated with different combinations of inorganic and organic fertilizers are presented in Figure 1. Results revealed that oxidizable organic carbon increased with increase in the period of incubation. The increase in organic carbon is more prominent in organic matter treated systems. As organic matter contains organic carbon, therefore addition of FYM increased the organic carbon content in soil. Highest amount of oxidizable organic carbon accumulated in soil in $\mathrm{T}_{5}$ closely followed by $\mathrm{T}_{6}$ treatment. Balanced fertilization increased the proliferation of microbial population and its activities in soil. The death of these microbes enhances microbial biomass carbon which in turn increases the oxidizable organic carbon content in soil (Sarkar, 1997) ${ }^{[21]}$. The increase in oxidizable organic carbon with the period of investigation particularly at the last stage is due to increase in number of microorganisms. Decomposition of dead cells of these organisms increased the organic carbon content in soil at the later stage of incubation (Premi, 2003) ${ }^{[22]}$. Earlier works of Abraham and Lal (2003) ${ }^{[23]}$ reported that the percentage of organic carbon in the soil increased due to integration of different nutrient sources. Statistical analysis of the results revealed that the treatments differ significantly among themselves. 


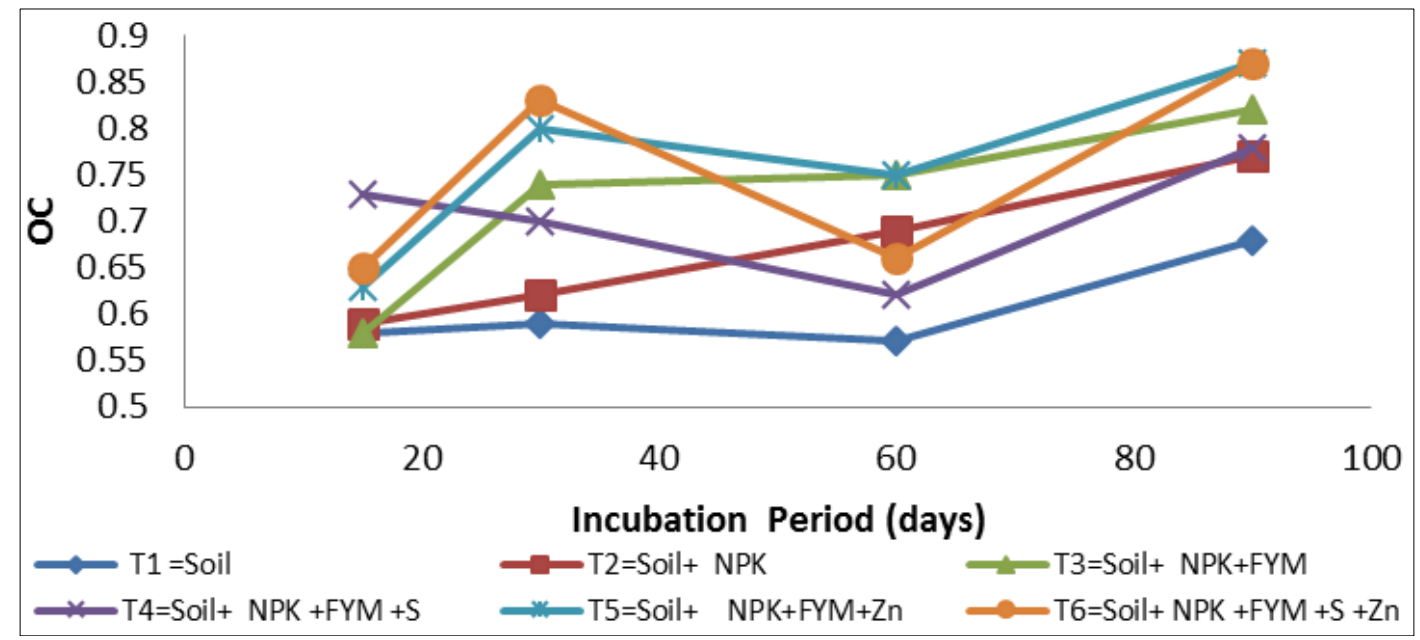

Fig 1: Influence of inorganic and organic amendments on changes in Organic Carbon content (\%)

\section{Microbial biomass carbon}

In general, microbial biomass carbon increased with increase in the period of incubation (Figure 2). The increase in microbial biomass carbon with time is due to proliferation of microbial activities in soil. Results also revealed that addition of organic matter further increased the microbial biomass carbon in soil. This is due to supply of energy rich materials for the growth and activities of microorganisms prevail in soil (Kanchikerimath and Singh, 2001) ${ }^{[24]}$. Treatment $\mathrm{T}_{5}$ and $\mathrm{T}_{4}$ are statistically at par with each other. Results clearly pointed out that biomass carbon was increased within 15 days very sharply and reached a near constant level after 30 days of incubation (Paul and Solaiman, 2004) ${ }^{[25]}$. In $\mathrm{T}_{6}, \mathrm{~T}_{5}$ and $\mathrm{T}_{4}$ treatments $\mathrm{MBC}$ results showed significant results for all the incubation stages due to balanced fertilization which help to proliferate microbial growth and in turn higher $\mathrm{MBC}$ in organic matter added under treatments. Results of treatments and stages of sampling as well as their interactions differ significantly.

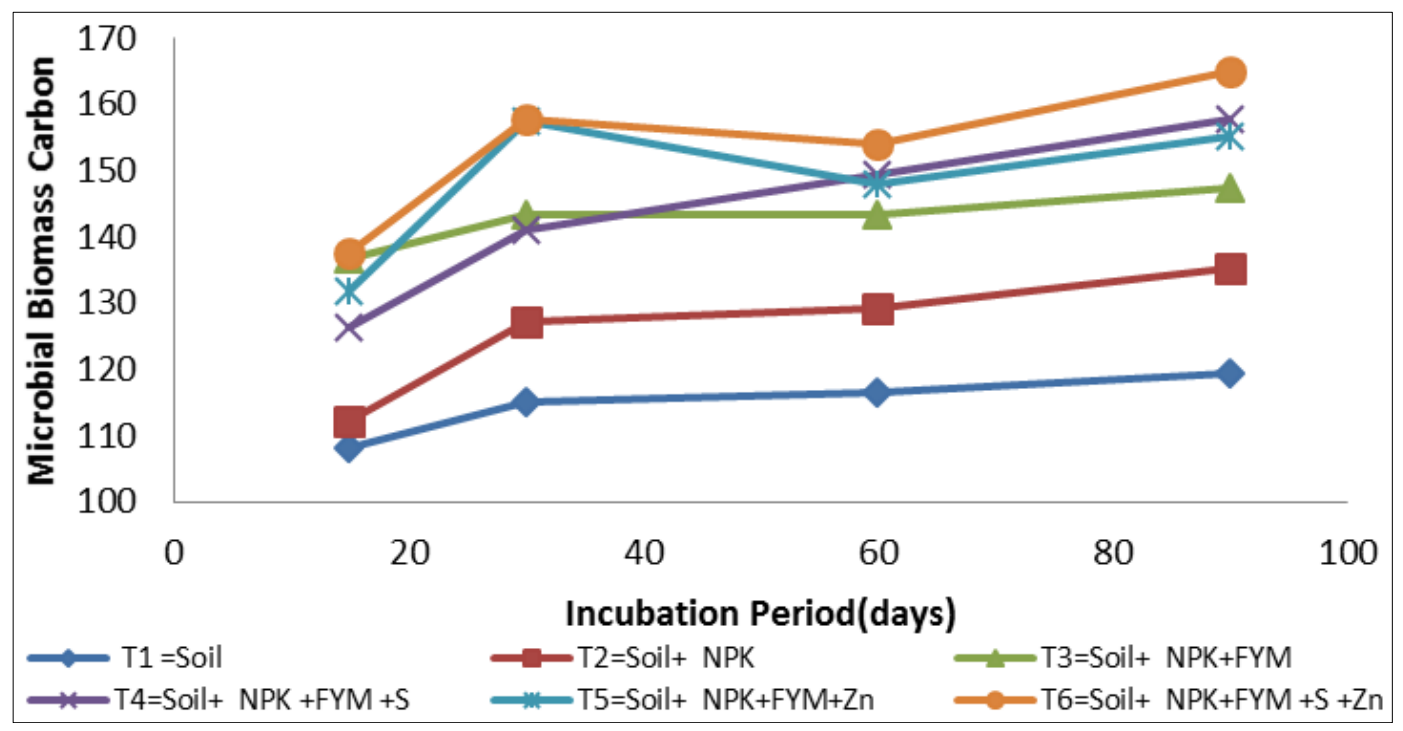

Fig 2: Influence of inorganic and organic amendments on changes in Microbial Biomass Carbon $\left(\mu \mathrm{g} \mathrm{kg}^{1}{ }^{1}\right)$

\section{Available N}

Irrespective of treatments, available $\mathrm{N}$ decreased up to $60^{\text {th }}$ (except in treatment $\mathrm{T}_{3}$ ) thereafter showed an increasing trend upto $90^{\text {th }}$ day of incubation (Table 3 ). The effect of added $\mathrm{N}$ fertilizer is well marked in all the treatments. The decrease in available $\mathrm{N}$ upto $60^{\text {th }}$ day of the experiment is due to consumption of $\mathrm{N}$ by the microbial population as well as losses through denitrification and volatilization (Burger and Venterea, 2008) ${ }^{[26]}$. As there is no plant in the system, exchangeable $\mathrm{NH}_{4}^{+}$which is consumed by the microbial population and converted to microbial biomass $\mathrm{N}$ again comes into available form leading to higher amount of available $\mathrm{N}$ in the system ((Kanchikerimath and Singh, 2001) ${ }^{[24]}$.

Table 3: Influence of inorganic and organic amendments on different soil parameters

\begin{tabular}{|c|c|c|c|c|c|c|}
\hline \multirow{2}{*}{ Treatments } & $\begin{array}{c}\text { Incubation } \\
\text { Period (Days) }\end{array}$ & $\begin{array}{c}\text { Av. N } \\
\text { kgha }^{-1}\end{array}$ & $\begin{array}{c}\text { Av. P } \\
\text { kgha-1 }^{-1}\end{array}$ & $\begin{array}{c}\text { Av. K kgha } \\
\mathbf{1}\end{array}$ & $\begin{array}{c}\text { Av. S } \\
\text { mgkg-1 }^{\mathbf{1}}\end{array}$ & $\begin{array}{c}\text { DTPA Ext.- } \\
\text { Zn mgkg- }^{\mathbf{~ m}}\end{array}$ \\
\hline \multirow{3}{*}{$\mathrm{T}_{1}=$ Soil } & 15 & 234.13 & 65.92 & 189.06 & 5.34 & 0.78 \\
\cline { 2 - 7 } & 30 & 174.14 & 64.43 & 166.5 & 11.12 & 0.84 \\
\cline { 2 - 7 } & 60 & 173.46 & 85.73 & 154.29 & 10.22 & 060 \\
\hline $\mathrm{T}_{2}=$ Soil + & 90 & 162.91 & 81.72 & 139.02 & 15.8 & 0.56 \\
\hline
\end{tabular}




\begin{tabular}{|c|c|c|c|c|c|c|}
\hline \multirow[t]{3}{*}{ NPK } & 30 & 175.06 & 52.28 & 240.48 & 19.58 & 1.02 \\
\hline & 60 & 168.13 & 94.00 & 175.12 & 12.36 & 0.74 \\
\hline & 90 & 226.79 & 83.13 & 173.62 & 18.25 & 0.78 \\
\hline \multirow{4}{*}{$\begin{array}{c}\mathrm{T}_{3}=\text { Soil }+ \\
\mathrm{NPK}+\mathrm{FYM}\end{array}$} & 15 & 274.73 & 167.38 & 263.41 & 10.22 & 0.98 \\
\hline & 30 & 210.58 & 107.19 & 257.01 & 19.06 & 1.20 \\
\hline & 60 & 240.7 & 159.34 & 218.09 & 14.96 & 1.32 \\
\hline & 90 & 252.73 & 144.81 & 207.33 & 19.6 & 1.84 \\
\hline \multirow{4}{*}{$\begin{array}{c}\mathrm{T}_{4}=\text { Soil+ } \\
\mathrm{NPK}+\mathrm{FYM} \\
+\mathrm{S}\end{array}$} & 15 & 256.28 & 146.55 & 259.07 & 16.74 & 1.10 \\
\hline & 30 & 203.96 & 132.35 & 205.63 & 33.28 & 1.32 \\
\hline & 60 & 194.46 & 157.98 & 224.05 & 28.22 & 1.24 \\
\hline & 90 & 237.23 & 160.20 & 182.26 & 26.84 & 1.02 \\
\hline \multirow{4}{*}{$\begin{array}{c}\mathrm{T}_{5}=\text { Soil+ } \\
\mathrm{NPK}+ \\
\text { FYM+Zn }\end{array}$} & 15 & 252.76 & 116.75 & 256.23 & 13.32 & 1.22 \\
\hline & 30 & 194.76 & 97.29 & 218.76 & 25.24 & 1.40 \\
\hline & 60 & 185.03 & 172.66 & 205.32 & 24.52 & 1.02 \\
\hline & 90 & 261.36 & 157.02 & 218.68 & 23.19 & 2.12 \\
\hline \multirow{4}{*}{$\begin{array}{c}\mathrm{T}_{6}=\text { Soil+ } \\
\mathrm{NPK}+\mathrm{FYM} \\
+\mathrm{S}+\mathrm{Zn}\end{array}$} & 15 & 266.4 & 100.69 & 218.83 & 18.55 & 1.56 \\
\hline & 30 & 196.06 & 109.25 & 205.9 & 28.5 & 1.92 \\
\hline & 60 & 202.88 & 194.21 & 197.27 & 25.67 & 1.34 \\
\hline & 90 & 238.95 & 158.20 & 189.35 & 30.32 & 2.48 \\
\hline \multicolumn{2}{|c|}{$\mathrm{SE}_{\mathrm{m}}$ (Tr x Days) } & 4.56 & 2.80 & 0.96 & 0.91 & 0.02 \\
\hline \multicolumn{2}{|c|}{$\mathrm{CD}(\mathrm{P}=0.05)$} & 12.97 & 7.96 & 2.75 & 2.6 & 0.04 \\
\hline
\end{tabular}

\section{Available $\mathbf{P}$}

Irrespective of treatments (except in control), in general, available phosphorus showed an decreasing trend up to $30^{\text {th }}$ then showed an increasing trend up to $60^{\text {th }}$ day and then slightly decreased up to the last stage of incubation (Table 3). Highest amount of accumulation of available phosphorus on $60^{\text {th }}$ day of experiment is due to mineralization of organic phosphorus as well as non utilization of available phosphorus by the growing crops. The decrease in available phosphorus at the last stage of incubation in some treatments is due to consumption of available phosphorus by the microorganisms and the conversion of available phosphorus into other inorganic and organic form with time (Clark, 1998) ${ }^{[27]}$. The decrease in available phosphorus at the last stage of incubation in some treatments is due to consumption of available phosphorus by the microorganisms and the conversion of available phosphorus into other inorganic and organic form with time (Antil and Singh, 2007) ${ }^{[28]}$. The effect of added treatment materials is very prominent in accumulation of available $P$. Addition of organic and inorganic fertilizers including micronutrients is essential for the proliferation of P-solubilizing organisms in soil (Buurash, 1997) ${ }^{[29]}$, which in turn increased the available $P$ content in soil (Fraser, 1994) ${ }^{[30]}$.

\section{Available K}

Irrespective of treatments, the amount of available $\mathrm{K}$ decreased with the period of investigation (Table 3 ). Addition of $\mathrm{K}$ fertilizer increases the available $\mathrm{K}$ content in the soil. This increase is predominant on $15^{\text {th }}$ day of the incubation study under all the treatments. Results in Table 3 further showed that highest amount of available $\mathrm{K}$ are accumulated in treatment $T_{3}$ on the $30^{\text {th }}$ day of the incubation study. This is perhaps due to release of higher amount of available $\mathrm{K}$ from FYM and inorganic source under favorable microbial growth. Similar results were also obtained by Antil and Singh (2007) [28].

\section{Available S}

Data in Table 3 represent changes in the amount of available $S$ in soil treated with different inorganic and organic fertilizers. Results revealed that in general, highest amount of available $\mathrm{S}$ is accumulated in soil on $30^{\text {th }}$ day of incubation. This is due to mineralization of higher amount organic matter present in soil. However, the accumulation of mineralized sulphur in soil depends upon treatment combinations (Saren and Saha, 2018) ${ }^{[31]}$. Available S slightly decreased from 30 to 60 day period of incubation and then again increased in the last stage of incubation except in treatment $T_{4}$ and $T_{5}$. Statistical analysis of the results, however, showed that the treatments differ significantly with each other. The stages of sampling as well as interaction between stages and treatments are also significant.

\section{DTPA Extractable Zn}

In general, the amount of DTPA-extractable $\mathrm{Zn}$ increased increased with the period of investigation except in control (Table 3). Highest amount of DTPA-extractable $\mathrm{Zn}$ was obtained in treatment $\mathrm{T}_{6}$ in all the sampling stages. Dash $(2015)^{[32]}$ stated that interaction effect of $\mathrm{Zn}$ with other nutrients is synergistic and higher than $S$. However, the combined effect of $\mathrm{Zn}$ and $\mathrm{S}$ was additive. Data are statistically significant with respect to treatments and stages of sampling as well as their interaction.

\section{Application of research}

The results of the laboratory experiment can be extrapolated under field condition. The results of field experiment may be then implemented in vast area of alluvial soil of West Bengal to raise rice crop with high yield.

\section{References}

1. Palm CA, Gachengo CN, Delve RJ, Cadisch G, Giller KE. Organic inputs for soil fertility management in tropical agroecosystems: Application of an organic resource database. Agric. Ecosyst. Environ. 2001; 83:2742.

2. Arbad BK, Ismail S. Effects of intergrated nutrient management on soyabean (Glycine max) safflower (Carthamus tinctorius) cropping system. Indian J. agron. 2011; 56:340-345.

3. Klikocka H, Barczak B, Szostak B, Kobiałka AJ. Elementology. 2017; 22(3):985-994.

4. AICRP-MSPE, Annual Ptrogress Report of All India Coordinated Research Project on Micronutrient, Secondary and pollutant Elements, ICAR-IISS, Bhopal, 2015. 
5. Marschner H. Mineral Nutrition of Higher Plants. $2^{\text {nd }}$ ed. Academic Press, London, 1995, 889.

6. Cakmak I. Possible role of Zinc in protecting plant cells from damage by reactive oxygen species. New Phytologist. 2000; 146:186-205

7. Niraj VPS, Kumar A, Prakash V. Effect of sulphur and zinc levels on yield and nutrient uptake by hybrid rice in partially reclaimed sodic soil. Int. J Agricultural Sci. 2014; 10(1):241-243

8. Jackson ML. Soil Chemical Analysis. Prentice Hall of India. Pvt. Ltd., New Delhi, 1973, 497-503.

9. Piper CS. Soil and Plant analysis. Hans Publishers, Bombay, 1966.

10. USDA. A basic system of soil classification for making and interpreting soil surveye. Soil taxonomy., Washington, D. C, 1975, 754.

11. Schollenberger CJ, Simon RH. Determination of exchange capacity and exchangeable bases in soil. Soil Sci. 1945; 59:13-24.

12. Walkley A, Black IA. An examination of the Degtjareff method for determining organic Carbon in Soils. Effect of variations in Digestion conditions and of inorganic soil constituents. Soil Sci. 1934; 63:251-263.

13. Baruah TC, Barthakur HP. A text book of soil analysis, Vikash Publishing House Pvt. Ltd., Bangalore, 1997, 334.

14. Stevenson FJ. Nitrogen-Organic forms. In Sparks, D.L. (ed). Methods of soil Analysis; Chemical methods part 3. Soil Sci. Am. Book Series No 5, ASA-SSSA, Madison, NI, 1996, 1185-1200.

15. Bremner JM, Keeney DR. Steam distillation methods for determination of ammonium, nitrate, and nitrite. Anal. Chim. Acta. 1965; 32:485-95.

16. Olsen SR, Cole CV, Watanable FS, Rean LA. Estimation of available phpsphorus in soils by extraction with sodium bicarbonate. United States Department of Agriculture Circular, 1954, 939.

17. Chesnin L, Yien CH. Turbidimetric determination of Available sulphate. Proc. Soil Sci. Soc. Amer. 1951; 15:149-151.

18. Lindsay WL, Norvell WA. Development of a DTPA test for zinc, iron, manganese, and copper. Soil Sci. Soc. Am. J. 1978; 42:421-428.

19. Joergensen RG. Microbial biomass In: Alef, K., Nannipieri, P. (Eds) Methods in Applied Microbiology and Bio- Chemistry, Academic Press, 1995, 382-386

20. Walter $\mathrm{T}$ Federar. Experimental design, Theory and Application, Oxpord and IBH Pub. Co. Calcutta, 1927.

21. Sarkar S, Singh SR. Integrated nutrient management in relation to soil fertility and yield sustainability under dry land farming. Indian J Agric. Sci. 1997; 67(9):431-433.

22. Premi OP. Integrated nutrient supply for sustainable rice production in an acid Alfisol. Indian J agric. Res. 2003; 37(2):132-135.

23. Abraham T, Lal RB. Strategies for INM technology in sustainable edapho-cultivar management for a legume based (black gram-wheat-greengram) cropping system for the inceptisols in the NEPZ. Crop Res. 2003; 26(1):17-25.

24. Kanchikerimath M, Singh D. Soil organic matter and biological properties after 26 years of maize-wheatcowpea cropping affected by manure and fertilization in a Cambisol in semiarid region of India, Agric. Ecosyst. Environ. 2001; 86:155-162.
25. Paul GC, Solaiman ARM. Changes of microbial biomass carbon and nitrogen in upland sugarcane soil amended with different organic materials. Common. Soil Sci. Anal. 2004; 35(17/18):2433-2447.

26. Burger M, Venterea RT. Nitrogen immobilization and mineralization kinetics in cattle, hog and turkey manure applied to soil. Soil Sc. Soc. Am. J. 2008; 72:1570-1579.

27. Clark MS, Horwarth WR, Shennan C, Scow KM. Changes in Soil Chemicals Properties Resulting from Organic and Low-Input Farming practices, Agronomy Journal. 1998; 90:662-671.

28. Antil RS, Singh M. Effects of organic manures and fertilizers on organic matter and nutrient status of the soil. Arch. Agron. Soil Sc. 2007; 53:519-528.

29. Buresh RJ, Smithson RC, Hcllums DT. Building soil phosphorus capital in Africa. In: replenishing soil fertility in Africa, Buresh, R.J., Sanchey, P.A., Calhoun., F., Eds., SSSA special publ. 51., SSSA: Madison, Wisconsin, USA, 1997, 97-109.

30. Fraser PM, Haynes RJ, Williams PH. Effects of pasture improvement and cultivation on microbial biomass, enzyme activity and composition and size of earth worm populations, Biol. Fertil. Soils. 1994; 17:185-190.

31. Saren S, Saha D. Dynamics of sulphur in a typic haplaquept soil in relation to rapeseed. J Indian Chem. Soc. 2018; 95:1-6.

32. Dash AK, Singh HK, Mahakud T, Pradhan KC, Jena D. Interaction Effect of Nitrogen, Phosphorus, Potassium with Sulphur, Boron and Zinc on Yield and Nutrient Uptake by Rice Under Rice - Rice Cropping System in Inceptisol of Coastal Odisha. Int. Res. J Agric. Sci. Soil Sci. 2015; 5(1):14-21. 